\title{
Do Eco-Friendly Floral Preservative Solutions Prolong Vase Life Better than Chemical Solutions?
}

\author{
Toan Khac Nguyen and Jin Hee Lim*
}

check for updates

Citation: Nguyen, T.K.; Lim, J.H. Do Eco-Friendly Floral Preservative Solutions Prolong Vase Life Better than Chemical Solutions? Horticulturae 2021, 7, 415. https://doi.org/ 10.3390/horticulturae7100415

Academic Editor: Douglas

D. Archbold

Received: 20 September 2021

Accepted: 15 October 2021

Published: 19 October 2021

Publisher's Note: MDPI stays neutral with regard to jurisdictional claims in published maps and institutional affiliations.

Copyright: (c) 2021 by the authors. Licensee MDPI, Basel, Switzerland. This article is an open access article distributed under the terms and conditions of the Creative Commons Attribution (CC BY) license (https:// creativecommons.org/licenses/by/ $4.0 /)$.
Department of Plant Biotechnology, Sejong University, Seoul 05006, Korea; toanchrys@sju.ac.kr

* Correspondence: jinheelim@sejong.ac.kr

\begin{abstract}
Cut flowers have become an export income in the global floriculture market. They have multiple uses, such as for home beautification, in ceremonies (including weddings and funerals), and as symbols of love, appreciation, respect, etc., in humane society. Each type of cut flower has a different vase life and the longevity of their freshness is linked to preharvest, harvest, and postharvest tools and conditions. The postharvest quality and vase life must be considered in order to obtain the desirable qualities of cut flowers, and factors that affect this are important in the floral industry. The use of floral preservative solutions is good practice for prolonging the vase life of cut flowers. Currently, the eco-friendly solutions, which are used as floral preservatives for extending cut flower vase life, have been discovered to be a low-cost and organic alternative as compared to chemical solutions. However, there are certain problems associated with the use of chemical and eco-friendly solutions. In this review, we summarize several potential approaches to improve flower vase life and discuss the best choices for holding-preservative-solution practices.
\end{abstract}

Keywords: cut flower; floral postharvest storage; flower industry; flower longevity; postharvest quality; postharvest technique

\section{Introduction}

The vase life of cut flowers can be characterized as the extended survival of cut flowers in a vase, which is affected by preharvest and postharvest conditions. The floral market is recognized as a global market that links countries together, and the time for exporting is willing reduced by a few days or within a week. The fresh condition of cut flowers is maintained by the use of a preservative solution, postharvest, to provide fresh flowers with a long vase life to the final customer. Each type of cut flower has a particular vase life: the short vase life group (less than 5 days) includes dahlia [1], iris [2], daffodils [3], delphinium [4], and alstroemeria [5]; the medium vase life group (6 14 days), such as protea [6], gladiolus [7], ginger [8], primrose [9], heliconia [10], marigolds [11], snapdragons [12], orchids [13], and rose [14]; and the long vase life group (2 weeks 4 weeks), such as tulips [15], anthuriums [16], carnations [17], and chrysanthemums [18].

As flowers are the symbols of spectacular attention in nature, they endure a lot of different types of postharvest damage, such as dehydrated cause injury, insufficient temperature changes, fungi (Botrytis cinerea), mechanical impairment, and bacterial attachment that affect the fresh quality of the arrangement and its vase life [1-6]. The beneficial method for extending the long vase life of cut flowers is being studied. Suitable handling, eco-friendly for a safe environment, non-harmful, and low price are mecessary because poor postharvest practices affect quality losses in cut flowers [19-22]. The most common symptoms are wilting senescence, which is linked to the loss of cell turgor pressure by a failure of water uptake due to stem blockage by air; microbial growth; and physiological plugging [23-25]. Additionally, leaf chlorophyll and petal pigments, such as anthocyanin, carotenoids, and betalains, decline, causing color fading, missing, or breakdown [26-30]. During senescence, the increasing activity of proteases is contrary to the decrease in total protein by rapid proteolysis [31-33]. Moreover, the levels of various lipids decrease, 
which is linked to cut flower senescence [34-38]. Cellular activities, such as increased respiration and enzymatic hydrolysis, are two processes that occur during senescence in cut flowers [39-41]. Thus, the findings of in-depth studies on postharvest senescence physiology must be applied and optimized to improve cut flower vase life. In addition, various techniques have been used to reduce postharvest disorders and extend the vase life of cut flowers to provide high value for floriculture producers. In this review, we extend the recommendations by considering and summarizing several approach factors that are affected by postharvest quality to improve vase life. We also give information on eco-friendly solutions and provide an opinion on the best application of the preservative solution to extend flower vase life.

\section{The Approach Factors for Floral Preservative Solutions}

Preharvest factors, including growing conditions or genetic quality, affect floral vase life, which is also linked to postharvest conditions [42-46]. Floral preservative solutions have generally become the best choice for growers, wholesalers, retailers, and customers in the floral industry to prolong vase life and control the quality of cut flowers [47]. Preservative solutions are commonly efficient in many ways, such as inactivating physiological processes, reducing senescence and transpiration, preventing the effects of ethylene, developing petal color, increasing bud and flower opening, preventing bacterial growth, and enhancing water uptake $[14,47,48]$. Preservative solutions are derived from a mixture of sugars, germicides or biocides, salts, and growth regulators. They increase water uptake by acidifying solutions, reduce microbial growth, and contribute carbohydrates required for the metabolic activities of cut flowers [47-49]. Currently, environmentally-friendly preservative solutions are being developed using eco-friendly powders from plants [47]. In this review, we separate two kinds of floral preservative solutions: chemical and eco-friendly. There are three preservative treatments that can be practiced for prolonging cut flower vase life: bud opening, pulsing, and holding solutions.

\subsection{Chemical Preservative Solution}

\subsubsection{Bud Opening Development}

In bud opening development using a preservative solution, growers harvest the buds at an early stage of development and hold them in a solution containing sucrose, plant hormones, and germicides before the opening of the immature buds. Previous studies have shown that low sugar concentrations are considered effective for bud opening of lily [50], chrysanthemums [51], carnation [52], rose [53], snapdragon [54], and gladiolus flowers [55]. Furthermore, the floral postharvest life is extended by checking for low temperature, humidity, and ethylene in shipment spaces $[47,56,57]$.

\subsubsection{Pulsing Treatment}

Pulsing involves treating the flowers or buds for $16-20 \mathrm{~h}$ with higher concentrations of sucrose [55,58-60]. Each species or cultivar responds differently to the sucrose concentration [55]. Chemical pulsing treatments include silver thiosulfate (STS) [18,61,62], hydroquinone (HQ) [34,58,63], 8-hydroxyquinoline sulfate (8-HQS) [39], silver nitrate $\left(\mathrm{AgNO}_{3}\right)$ [64], aminooxyacetic acid (AOA) [65,66], calcium dichloride $\left(\mathrm{CaCl}_{2}\right)$ [67], cobalt chloride $\left(\mathrm{CoCl}_{2}\right)$ [60], aluminum sulphate $\left(\mathrm{Al}_{2}\left(\mathrm{SO}_{4}\right)_{3}\right)$ [68], chlorine dioxide $\left(\mathrm{ClO}_{2}\right)$ [69], and benzyladenine $\left(\mathrm{C}_{12} \mathrm{H}_{11} \mathrm{~N}_{5}\right)$ [70,71]. High concentrations of silver nitrate solution have been used in studies on the pulsing treatment of many cut flowers, including gerbera [72], gladiolus [73], chrysanthemum [74], carnation [74,75], Persian buttercup [64], herbaceous peony [63], and rose [76]. This pulsing step is necessary for a prolonged storage period or for export outside the country. Moreover, pulsing treatment can improve flower life, promote flower opening, and recover flower size and petal color by controlling osmotic regulation [55]. 


\subsubsection{Holding Solutions (Vase Solutions)}

Holding solutions, which contain a combination of carbohydrates (usually sugar), plant growth regulators, germicides, ethylene inhibitors, mineral salts, and organic acids are used to extend the vase life of cut flowers [55,77]. Each flower species and cultivar is adapted to various constituents and concentrations in the holding solution $[55,78]$. The sugar provides energy for plant respiration, and the germicides affect and kill harmful bacteria, and its action prevents plant tissue plugging [49,79].

\subsubsection{Sugar}

Sugar is the gold key of floral energy sources as it has positive effects on many physiological activities and metabolic reactions, including bud opening, flower size increase, flower color production, vase life extension, inhibition of ethylene synthesis, and control of water uptake $[55,80,81]$. There are many studies on sugar solutions for improving flower vase life, and effective sugar concentrations differ for different species [12,34,82]. Respiration is an important metabolic process in cut flowers and is linked to stored starch and sugar reserves for respiration during postharvest life $[60,83]$. The application of exogenous soluble sugars, such as sucrose, glucose, or fructose in solutions can be used as the energy for extending flower vase life $[84,85]$. The gradients of sugar concentration were studied and depended on the level of sugar concentration in floral preservative treatments. A high sugar concentration is used for the pulsing treatment, a medium sugar concentration is used for bud opening, and a low concentration of sugar is usually used for vase holding solutions $[12,83]$. Sucrose is the most frequently used form of sugar to prolong the vase life of cut flowers, and is correlated with the water balance $[48,55,81,83,86]$. Sugars are also known as osmotically active molecular structures that improve water relations and make turgid hydrolyzed sugars $[39,81,85,87]$. It can increase the thickness and lignification of the vascular tissues of cut flowers [88]. Moreover, sucrose can affect stomatal closure and reduce water loss [89]. Ichimura et al. (1998) identified that sucrose affects anthocyanin expression by influencing the gene expression for the biosynthesis of anthocyanin [81]. In contrast to these positive effects, sucrose can be linked to the effect of abscisic acid (ABA), which increases senescence $[90,91]$.

\subsubsection{Germicides or Biocides}

Germicides or biocides are economically available antimicrobial chemicals that are intended to block the growth of bacteria, fungi, and some microorganisms that are present in flower vases [92-96]. Bent-neck symptoms occur when the floral xylem is attacked by bacteria or fungi, which block water uptake, resulting in a short flower vase life [92,97]. As indicated in previous studies, the number of bacteria and fungi in the vase water is related to the vase life of cut flowers $[47,55,98,99]$. The hydraulic conductivity of flower stems decreases with the number of bacteria per cut flower stem fresh weight [100-102]. A number of germicide solutions have been used to extend the vase life of cut flowers, including the silver compounds: STS [12,103] and $\mathrm{AgNO}_{3}$ [103]); chlorine compounds (sodium hypochlorite, sodium dichloroisocyanurate, and $\mathrm{ClO}_{2}[5]$ ), and certain other compounds, such as 8-HQS [12], 8-Hydroxyquinoline citrate (8-HQC) [104], salicylic acid (SA) [105], calcium [106], calcium nitrate [107], aluminum sulfate [108,109], isothiazolinone [49], and quaternary ammonium chloride [110]). To prevent microbial growth, a sugar solution is always added to a biocide solution [78]. In cut flower roses, germicide treatments preserve the hydraulic conductance of the cut flower stems [92]. Aluminum sulfate solution decreases microbial growth, prevents bacterial growth, increases water uptake, delays senescence, and extends the vase life of cut rose, eustoma, and gladiolus flowers [111]. In a study on lisianthus 'Mariachi Bleu Fonce' cut flowers, the combination of preservative solutions with sucrose, citric acid, and aluminum sulfate extended vase life for more than 13 days compared to that of a water control [82]. In a study on Rosa hybrida L. 'Beast' cut flowers, an investigation into the antimicrobial effect of a $\mathrm{ClO}_{2}$ holding solution containing $2 \%$ sugar showed that the combination of solutions extends the postharvest 
vase life of the cut roses [112]. 8-Hydroxyquinoline salts prevent bacterial growth, delay senescence, and reduce water uptake in gerbera flowers [83,92]. Silver thiosulfate and 8 -HQC are usually used as the most effective biocides and are the most active inhibitors of ethylene production $[12,83]$. Some cut flowers are familiar with STS solutions such as carnation, orchids, gypsophila, gladiolus, gerbera, snapdragon, alstromaeria, agapanthus, anemone and sweet pea. In dendrobium and gladiolus cut flowers, 8-HQS is most effective in preventing microbial growth, reducing respiration rate, increasing water uptake, and extending vase life [113]. Nanometer-sized silver particles (NS) are used as an effective solution for extending the vase life of some cut flowers, including carnations, gerberas, acacias, and roses [114]. The volume ratio of NS particles with large surfaces increases their links with microorganisms, thereby preventing the negative effects of microbes in vase solutions $[115,116]$. The bactericidal properties of NS also have a positive effect on water uptake. In cut flower roses, pulse treatments for $1 \mathrm{~h}$ with 50 and $100 \mathrm{mg} \mathrm{L}^{-1} \mathrm{NS}$ solutions showed an increase in vase life and a suppressed reduction in fresh weight during the vase period. In addition, the NS solutions affect the stem hydraulic conductivity, decreasing stomatal conductance. They also delay $R h$-PIP2 aquaporin gene expression [117]. Silver nitrate and nano-silver also inhibit the ethylene hormone [118]. They can reduce microbial attacks and can be effectively applied to various types of cut flowers, including aster, gerbera, gladiolus, tuberose, carnation, chrysanthemum, phalaenopsis, and snapdragon [23]. Preserving solutions containing a combination of silver compounds and 8-HQC or 8-HQS are environmental hazards because they contain heavy metal compounds $[49,110]$. Isothiazolinone and quaternary ammonium chloride are widely used as they are safe, stable, broad-spectrum, and efficient biocides for inclusion in floral preservative solutions [49,79]. A number of preservative solution compounds, including lime or lime soda, aspirin tablets, and essential plant oils are used as biocides or acidifiers in natural homemade solutions [21,49].

\subsection{Eco-Friendly Floral Preservative Solution}

In chrysanthemum 'Arctic Queen White' cut flowers, the use of thyme oil $\left(500 \mathrm{mg} \mathrm{L}^{-1}\right)$ or clove oil $\left(250 \mathrm{mg} \mathrm{L}^{-1}\right)$ produces the longest vase life in both seasons, and reduces bacterial growth [21].

In 'Haesal' cut spray roses, Ha et al. (2019) investigated various pretreatment solutions of Scutellaria baicalensis Georgi extract (SC) solution, hydrosol solution, and 1\% sucrose [48]. The results showed that $300 \mu \mathrm{L} \cdot \mathrm{L}^{-1}$ of SC was the most effective preservative solution with some beneficial effects, such as prolonging vase life, inhibiting bacterial growth, improving fresh weight, enhancing water uptake, and improving water balance [48]. In research on the 'Jinny' cut rose cultivar, natural antimicrobial powders from chrysanthemums and plants of the Ranunculaceae have been extracted and considered as alternative preservative solutions in the cut flower industry [119]. In a study on the cut rose 'Sonia', treatment with $20 \mathrm{mg} \mathrm{L}^{-1}$ tea-seed saponins significantly prolongs the vase life [120]. In research on the cut rose 'Carola', the effects of green tea extract (GTE) powder at $2.0 \mathrm{~g} \mathrm{~L}^{-1}$ were compared with preservatives such as $2 \%(w / v)$ sucrose, $200 \mathrm{mg} \mathrm{L}^{-1} 8$-HQC plus $2 \%(w / v)$ sucrose, or $0.2 \mathrm{mM}$ STS in the vase solution. The results showed that the GTE powder treatment at $2.0 \mathrm{~g} \mathrm{~L}^{-1}$ extends the flower vase life and reduces the fresh weight loss, most likely because of the effects of its high antioxidative and antimicrobial properties on cut roses [121].

Studies of homemade floral preservatives on cut 'ABC Blue' lisianthus (Eustoma grandiflorum), 'Maryland Plumblossom' snapdragon (Antirrhinum majus), 'Mid Cheerful Yellow' stock (Matthiola incana), and 'Deep Red' Benary's zinnia (Zinnia violacea) were investigated as a 48-h grower treatment or continuous retailer/consumer application. Solutions containing $500 \mathrm{~mL} \mathrm{~L}^{-1}$ lemon/lime soda or $400 \mathrm{mg} \mathrm{L}^{-1}$ citric acid plus $20 \mathrm{~g} \mathrm{~L}^{-1}$ sugar alone exhibit the best postharvest performance of all tested species [49].

A study on gladiolus has shown that a $2 \%$ concentration of Calotropis procera leaf extract (CPLE) extends the maximum vase life up to 14.5 days, open florets $(64 \%)$ and RFW $(40 \%)$ compared to the effects of Moringa oleifera leaf extract (MOLE) and Mentha piperita 
leaf extract (MPLE). Therefore, CPLE at $2 \%$ appears to be an effective natural preservative to extend the vase life of gladiolus cut spikes [122].

Aloe vera (Aloe vera barbadensis) and moringa (Moringa oleifera Lam.) solutions were studied and compared with salicylic acid and calcium chloride solutions for prolonging vase life of cut Heliconia 'Golden Torch' flowers [123]. The combination solution of Aloe vera at $5.0 \%$ and sucrose $4 \%$ showed the best result in water uptake, provided a percentage of maximum increase in open bracts $(67.4 \%)$, and gave the highest relative water content (RWC) $(78.9 \%)$ [123].

Piper betle leaf extract (PbLE) was studied for extending vase life and holding quality of cut spike of tuberose [124]. Four treatment solutions including the control as distilled water, 3\% sucrose (T1), 3\% sucrose + $100 \mathrm{ppm}$ 5-SSA (T2), 3\% sucrose + $50 \mathrm{ppm}$ PbLE (T3), were screened. The results showed that PbLE in T3 might have a significant role in inducing antioxidant enzyme systems at the senescence period, decreasing lipid peroxidation, and increasing membrane stability. These results suggest that T3 solution maintains spike freshness and dry weight, enhances antioxidative defense, maintains membrane integrity to delay senescence in cut spike of tuberose [124].

The use of eco-friendly compounds, which were chitosan $\left(25\right.$ and $\left.50 \mathrm{mg} \mathrm{L}^{-1}\right)$, thymol (25 and $50 \mathrm{mg} \mathrm{L}^{-1}$ ), and green silver nanoparticles $\left(25\right.$ and $50 \mathrm{mg} \mathrm{L}^{-1}$ ) with control (distilled water) and sucrose $(2 \%)$, were studied on the postharvest of the cut carnation "Tabor". The results showed the cut carnation vase life was extended by the inclusion of either 25 or $50 \mathrm{mg} \mathrm{L}^{-1}$ chitosan (17 days) or either $50 \mathrm{mg} \mathrm{L}^{-1}$ green silver nanoparticles (15.7 days) as compared with control (10 days) [125].

The vase life study of Gladiolus spikes was investigated by moringa leaf extract (MLE) with various concentrations $(0,1,2,3,4 \%)$. All MLE concentrations significantly prolonged the vase life and showed the results of 10 days longer using 3\% MLE. According to MLE treatment, the floret opening was improved and the weight loss was reduced in cut spikes. MLE 3\% showed the effects on the oxidative stress-induced in the cut spike, maintained photosynthetic pigments and water relations. Therefore, MLE 3\% should be applied as a potential-promising eco-friendly preservative solution for cut flowers [126].

\section{Further Investigations for Handling Eco-Friendly Preservative Solutions in the Flower Industry}

Commercial floral preservatives should provide many more benefits: they are reported to extend vase life, improve flower opening, increase water uptake, control fresh weight, retain flower pigment, and decrease ethylene sensitivity $[19,55,83]$. The handling of ecofriendly preservative solutions for cut flowers will be managed by various factors such as inhibition of bacterial growth, vase life extension, promotion of a positive water balance, improvement in fresh weight, enhancement of water uptake, and inhibition of the action of ethylene. The benefits of eco-friendly preservative solutions include opacity reduction, inhibition of viscid substances in the stem, restriction of disagreeable odor formation in the stem, vase life extension, and a decrease in fungi and bacteria in the vase solution. The drawbacks to the use of eco-friendly preservative solutions are (1) that many cut flower species do not need any nutritional source, or source of carbohydrates, and (2) the lack of available information on the effectiveness of eco-friendly preservative solutions on the postharvest longevity and quality of cut flowers, especially preservatives derived from natural plant substances. To overcome these drawbacks, a new eco-friendly preservative solution should be developed. This should include a combination of sucrose, citric acid, and biocides, which could provide an effective natural preservative because citric acid and biocides control the growth of microorganisms, whereas sucrose mediates the osmotic potential of the cut flowers by blocking the action of ethylene. Another option is the use of powder extracts from natural plants such as Asteraceae species and other plants because these are safe for human health. However, eco-friendly preservative solutions are determined as natural solutions with maintenance limitations. Do eco-friendly preservative solutions prolong vase life better than chemical solutions? The answer to this question requires further research; however, we can look forward to having low cost, friendly with 
the environment, especially that the eco-friendly preservative solution is not harmful to people and animals in the future (see Figure 1).

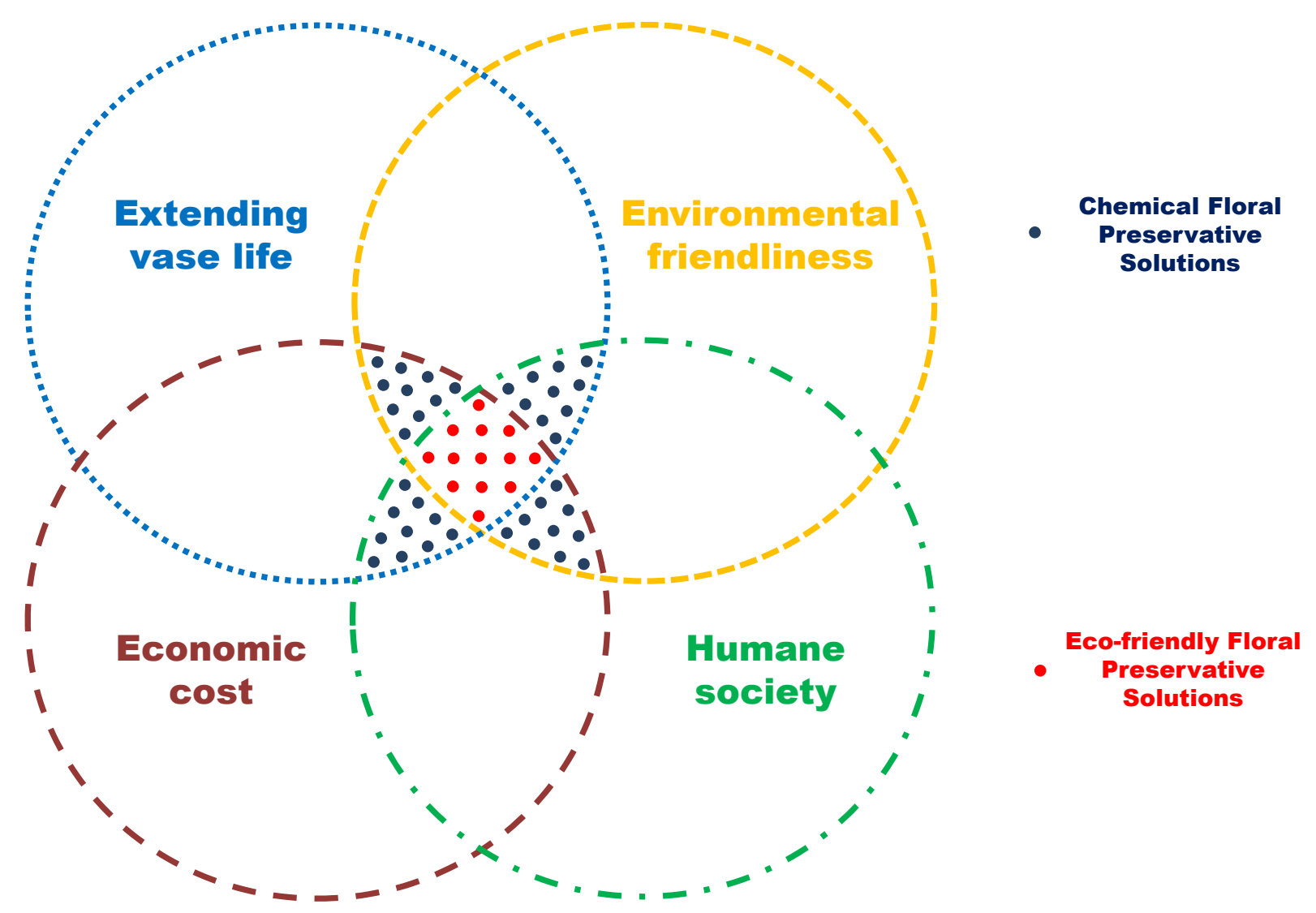

Figure 1. Dimensions of further development of floral preservative solutions.

\section{Conclusions}

By reviewing the different approaches and factors associated with the use of floral preservative solutions for the development of proper handling in the cut flower industry, we have not only helped florists and scientists to recognize appropriate preservative solutions, but have also provided a synthesis of the considerations associated with promoting the vase life of cut flowers using preservative solutions. Research aimed at expanding the range of preservative solutions for cut flowers must be ongoing, and the development of eco-friendly, natural preservative solutions must be prioritized in the cut flower industry.

Author Contributions: T.K.N. wrote and revised the manuscript. J.H.L. designed and supervised the project. All authors have read and agreed to the published version of the manuscript.

Funding: This work was supported by the Korea Institute of Planning and Evaluation for Technology in Food, Agriculture, Forestry and Fisheries (IPET) through the Export Promotion Technology Development Program, funded by the Ministry of Agriculture, Food and Rural Affairs (MAFRA) (No. 617076-05-5-SB110).

Institutional Review Board Statement: Not applicable.

Informed Consent Statement: Not applicable.

Data Availability Statement: The data presented in this study are included in this article.

Acknowledgments: We would like to thank all members of the Floriculture Lab.

Conflicts of Interest: The authors declare no conflict of interest regarding the publication of this paper. 


\section{References}

1. Onozaki, T.; Azuma, M. Breeding for long vase life in Dahlia (Dahlia variabilis) cut flowers. Hort. J. 2019, 88, 521-534. [CrossRef]

2. Macnish, A.J.; Jiang, C.Z.; Reid, M.S. Treatment with thidiazuron improves opening and vase life of iris flowers. Postharvest Biol. Technol. 2010, 56, 77-84. [CrossRef]

3. Doorn, W.G.V. Effects of Daffodil flowers on the water relations and vase life of roses and tulips. J. Am. Soc. Hortic. Sci. 1998, 123, 146. [CrossRef]

4. Ahmad, I.; Rafiq, M.B.; Dole, J.M.; Abdullah, B.; Habib, K. Production and postharvest evaluation of selected exotic specialty annual cut flower species in Punjab, Pakistan. HortTechnology 2017, 27, 878. [CrossRef]

5. Macnish, A.J.; Leonard, R.T.; Nell, T.A. Treatment with chlorine dioxide extends the vase life of selected cut flowers. Postharvest Biol. Technol. 2008, 50, 197-207. [CrossRef]

6. Stephens, I.A.; Holcroft, D.M.; Jacobs, G. Postharvest treatments to extend vase life of selected proteaceae cut flowers. Acta Hortic. 2003, 602, 155-159. [CrossRef]

7. Murali, T.P.; Reddy, T.V. Postharvest physiology of gladiolus flowers as influenced by cobalt and sucrose. In Horticulture-New Technologies and Applications; Current Plant Science and Biotechnology in Agriculture book series; Prakash, J., Pierik, R.L.M., Eds.; Springer: Berlin/Heidelberg, Germany, 1991; Volume 12, pp. 393-396. [CrossRef]

8. Choresca, R.G.C.; Secretaria, L.; Bayogan, E. Vase life of cut Torch ginger (Etlingera elatior) inflorescences as influenced by stem length. Mindanao J. Sci. Technol. 2019, 17, 112-125.

9. Asadi-Kavan, Z.; Khavari-Nejad, R.A.; Iranbakhsh, A.; Najafi, F. Cooperative effects of iron oxide nanoparticle $\left(\alpha-\mathrm{Fe}_{2} \mathrm{O}_{3}\right)$ and citrate on germination and oxidative system of evening primrose (Oenthera biennis L.). J. Plant Interact. 2020, 15, 166-179. [CrossRef]

10. Sardinha, D.H.S.; Rodrigues, A.A.C.; Ribeiro, S.S.M.; Diniz, N.B.; Campos Neto, J.R.M.; Reis, F.D.O. Phytostimulants influence the vase life of Heliconia psittacorum CV. golden torch. Postharvest Biol. Technol. 2019, 155, 140-148. [CrossRef]

11. Ahmad, I.; Dole, J.M.; Amjad, A.; Ahmad, S. Dry storage effects on postharvest performance of selected cut flowers. HortTechnology 2012, 22, 463. [CrossRef]

12. Asrar, A.-W.A. Effects of some preservative solutions on vase life and keeping quality of snapdragon (Antirrhinum majus L.) cut flowers. J. Saudi Soc. Agric. Sci. 2012, 11, 29-35. [CrossRef]

13. Khunmuang, S.; Kanlayanarat, S.; Wongs-Aree, C.; Meir, S.; Philosoph-Hadas, S.; Oren-Shamir, M.; Ovadia, R.; Buanong, M. Ethylene induces a rapid degradation of petal anthocyanins in cut vanda 'Sansai Blue' orchid flowers. Front. Plant Sci. 2019, 10, 1004. [CrossRef]

14. Ha, S.T.T.; Kim, Y.-T.; Jeon, Y.H.; Choi, H.W.; In, B.-C. Regulation of Botrytis cinerea infection and gene expression in cut roses by using nano silver and salicylic acid. Plants 2021, 10, 1241. [CrossRef]

15. Gómez-Merino, F.C.; Ramírez-Martínez, M.; Castillo-González, A.M.; Trejo-Téllez, L.I. Lanthanum prolongs vase life of cut tulip flowers by increasing water consumption and concentrations of sugars, proteins and chlorophylls. Sci. Rep. 2020, 10, 4209. [CrossRef]

16. Elibox, W.; Umaharan, P. Morphophysiological characteristics associated with vase life of cut flowers of anthurium. HortScience 2008, 43, 825. [CrossRef]

17. Aalifar, M.; Aliniaeifard, S.; Arab, M.; Zare Mehrjerdi, M.; Dianati Daylami, S.; Serek, M.; Woltering, E.; Li, T. Blue light improves vase life of carnation cut flowers through its effect on the antioxidant defense system. Front. Plant Sci. 2020, 11. [CrossRef] [PubMed]

18. Sedaghathoor, S.; Narouei, Z.; Sajjadi, S.A.; Piri, S. The effect of chemical treatments (silver thiosulfate and putrescine) on vase life and quality of cut Chrysanthemum morifolium (Ram.) flowers. Cogent Biol. 2020, 6, 1754320. [CrossRef]

19. Asghari, R.; Salari, A.; Gharehdaghi, S. Effect of pulsing solution and packaging type under exogenous ethylene on physiological characteristics and post harvesting quality of cut roses (Rosa hybrida). Am.-Eurasian J. Agric. Environ. Sci. 2014, 14, $329-335$. [CrossRef]

20. Fanourakis, D.; Pieruschka, R.; Savvides, A.; Macnish, A.J.; Sarlikioti, V.; Woltering, E.J. Sources of vase life variation in cut roses: A review. Postharvest Biol. Technol. 2013, 78, 1-15. [CrossRef]

21. El-Sayed, I.M.; El-Ziat, R.A. Utilization of environmentally friendly essential oils on enhancing the postharvest characteristics of Chrysanthemum morifolium Ramat cut flowers. Heliyon 2021, 7, e05909. [CrossRef]

22. Van Meeteren, U. Causes of quality loss of cut flowers-A critical analysis of post-harvest treatments. Acta Hortic. 2009, 847, 27-36. [CrossRef]

23. De, L.C. Commercial Orchids; De Gruyter Open Poland: Warsaw, Poland, 2015. [CrossRef]

24. Naing, A.H.; Win, N.M.; Han, J.-S.; Lim, K.B.; Kim, C.K. Role of nano-silver and the bacterial strain enterobacter cloacae in increasing vase life of cut carnation 'Omea'. Front. Plant Sci. 2017, 8, 1590. [CrossRef] [PubMed]

25. Wongjunta, M.; Wongs-Aree, C.; Salim, S.; Meir, S.; Philosoph-Hadas, S.; Buanong, M. Involvement of ethylene in physiological processes determining the vase life of various hybrids of Mokara orchid cut flowers. Agronomy 2021, 11, 160. [CrossRef]

26. Tanaka, Y.; Sasaki, N.; Ohmiya, A. Biosynthesis of plant pigments: Anthocyanins, betalains and carotenoids. Plant J. 2008, 54, 733-749. [CrossRef]

27. Delgado-Vargas, F.; Jiménez, A.R.; Paredes-López, O. Natural pigments: Carotenoids, anthocyanins, and betalainsCharacteristics, biosynthesis, processing, and stability. Crit. Rev. Food Sci. Nutr. 2000, 40, 173-289. [CrossRef] [PubMed] 
28. Luo, J.; Shi, Q.; Niu, L.; Zhang, Y. Transcriptomic analysis of leaf in tree peony reveals differentially expressed pigments genes. Molecules 2017, 22, 324. [CrossRef]

29. Rodriguez-Amaya, D.B.; Carle, R. Chapter 7-Alterations of natural pigments. In Chemical Changes During Processing and Storage of Foods; Rodriguez-Amaya, D.B., Amaya-Farfan, J., Eds.; Academic Press: Oxford, UK, 2021; pp. 265-327. [CrossRef]

30. Harris, N.N.; Javellana, J.; Davies, K.M.; Lewis, D.H.; Jameson, P.E.; Deroles, S.C.; Calcott, K.E.; Gould, K.S.; Schwinn, K.E. Betalain production is possible in anthocyanin-producing plant species given the presence of DOPA-dioxygenase and L-DOPA. BMC Plant Biol. 2012, 12, 34. [CrossRef]

31. Diaz-Mendoza, M.; Velasco-Arroyo, B.; Santamaria, M.E.; González-Melendi, P.; Martinez, M.; Diaz, I. Plant senescence and proteolysis: Two processes with one destiny. Genet. Mol. Biol. 2016, 39, 329-338. [CrossRef]

32. Benchabane, M.; Goulet, C.; Rivard, D.; Faye, L.; Gomord, V.; Michaud, D. Preventing unintended proteolysis in plant protein biofactories. Plant Biotechnol. J. 2008, 6, 633-648. [CrossRef]

33. Rojo, E.; Zouhar, J.; Carter, C.; Kovaleva, V.; Raikhel, N.V. A unique mechanism for protein processing and degradation in Arabidopsis thaliana. Proc. Natl. Acad. Sci. USA 2003, 100, 7389. [CrossRef]

34. Lingfang, K.; Fan, L.; Ronghui, D.; Huaiting, G.; Shifeng, L.; Jihua, W. Effects of different preservatives on cut flower of Luculia pinceana: A novel fragrant ornamental species. HortScience 2021, 56, 795-802. [CrossRef]

35. Rogers, H.J. Is there an important role for reactive oxygen species and redox regulation during floral senescence? Plant Cell Environ. 2012, 35, 217-233. [CrossRef] [PubMed]

36. Naing, A.H.; Lee, K.; Arun, M.; Lim, K.B.; Kim, C.K. Characterization of the role of sodium nitroprusside (SNP) involved in long vase life of different carnation cultivars. BMC Plant Biol. 2017, 17, 149. [CrossRef] [PubMed]

37. Zhang, J.; Fang, H.; Huo, J.; Huang, D.; Wang, B.; Liao, W. Involvement of calcium and calmodulin in nitric oxide-regulated senescence of cut lily flowers. Front. Plant Sci. 2018, 9, 1284. [CrossRef] [PubMed]

38. Van Doorn, W.G.; Woltering, E.J. Physiology and molecular biology of petal senescence. J. Exp. Bot. 2008, 59, 453-480. [CrossRef] [PubMed]

39. Elhindi, K.M. Evaluation of several holding solutions for prolonging vase-life and keeping quality of cut sweet pea flowers (Lathyrus odoratus L.). Saudi J. Biol. Sci. 2012, 19, 195-202. [CrossRef] [PubMed]

40. Iqbal, N.; Khan, N.A.; Ferrante, A.; Trivellini, A.; Francini, A.; Khan, M.I.R. Ethylene role in plant growth, development and senescence: Interaction with other phytohormones. Front. Plant Sci. 2017, 8, 475. [CrossRef]

41. Costa, L.C.; Luz, L.M.; Nascimento, V.L.; Araujo, F.F.; Santos, M.N.S.; França, C.D.F.M.; Silva, T.P.; Fugate, K.K.; Finger, F.L. Selenium-ethylene interplay in postharvest life of cut flowers. Front. Plant Sci. 2020, 11, 2055. [CrossRef]

42. Davarynejad, E.; Tehranifar, A.; Ghayoor, Z.; Davarynejad, G.H. Effect of different pre-harvest conditions on the postharvest keeping quality of cut gerbera. Acta Hortic. 2007, 804, 205-208. [CrossRef]

43. Mohammadi, M.; Aelaei, M.; Saidi, M. Pre-harvest spray of GABA and spermine delays postharvest senescence and alleviates chilling injury of gerbera cut flowers during cold storage. Sci. Rep. 2021, 11, 14166. [CrossRef]

44. Rahmani, I.; Ahmadi, N.; Ghanati, F.; Sadeghi, M. Effects of salicylic acid applied pre- or post-transport on post-harvest characteristics and antioxidant enzyme activity of gladiolus cut flower spikes. J. Crop Hortic. Sci. 2015, 43, 294-305. [CrossRef]

45. Çelikel, F.G.; Karaçalý, Y. Effect of preharvest factors on flower quality and longevity of cut carnations (Dianthus caryophyllus L.). Acta Hortic. 1995, 405, 156-163. [CrossRef]

46. In, B.-C.; Seo, J.Y.; Lim, J.H. Preharvest environmental conditions affect the vase life of winter-cut roses grown under different commercial greenhouses. Hortic. Environ. Biotechnol. 2016, 57, 27-37. [CrossRef]

47. Nguyen, T.K.; Jung, Y.O.; Lim, J.H. Tools for cut flower for export: Is it a genuine challenge from growers to customers? Flower Res. J. 2020, 28, 241-249. [CrossRef]

48. Ha, S.T.T.; Kwon, M.J.; Nguyen, T.K.; Lim, J.H. Improvement in postharvest quality of cut spray roses 'Haesal' (Rosa hybrida L.) by pretreatment with Scutellaria baicalensis Georgi extract. Flower Res. J. 2019, 27, 177-185. [CrossRef]

49. Ahmad, I.; Dole, J.M. Homemade floral preservatives affect postharvest performance of selected specialty cut flowers. Hort. Technol. Hortte. 2014, 24, 384. [CrossRef]

50. Han, S.S. Role of sugar in the vase solution on postharvest flower and leaf quality of oriental lily 'Stargazer'. Hort. Sci. 2003, 38, 412. [CrossRef]

51. Trusty, S.E.; Miller, W. Postproduction carbohydrate levels in pot chrysanthemums. J. Am. Soc. Hortic. Sci. 1991, 116, 1013-1018. [CrossRef]

52. Park, J.E.; Thi, L.T.; Ya, L.; Jeong, B.R. Sucrose concentration, light intensity, and $\mathrm{CO}_{2}$ concentration affect growth and development of micropropagated carnation. Flower Res. J. 2018, 26, 61-67. [CrossRef]

53. Kazuo, I.; Masayuki, K.; Ryo, N.; Yoshihiko, K.; Kunio, Y. Soluble carbohydrates and variation in vase-life of cut rose cultivars 'Delilah' and 'Sonia'. J. Hortic. Sci. Biotechnol. 2005, 80, 280-286. [CrossRef]

54. Rabiza-Świder, J.; Skutnik, E.; Jędrzejuk, A.; Rochala-Wojciechowska, J. Nanosilver and sucrose delay the senescence of cut snapdragon flowers. Postharvest Biol. Technol. 2020, 165, 111165. [CrossRef]

55. Reid, M. Handling of Cut Flowers for Export; Proflora Bulletin: Bogotá, Colombia, 2009; pp. 1-26.

56. Poonsri, W. Effect of modified and controlled atmosphere storage on enzyme activity and senescence of Dendrobium orchids. Heliyon 2020, 6, e05070. [CrossRef] 
57. Carlson, A.S.; Dole, J.M. Determining optimal production temperature, transplant stage, and postharvest protocols for cut 'Esprit' penstemon. Hort. Technol. Hortte. 2014, 24, 71. [CrossRef]

58. Srilaong, V.; Buanong, M. Effect of hydroquinone pulsing treatment on vase life of cut rose. Acta Hortic. 2007, 755, 451-456. [CrossRef]

59. Eason, J.R. Sandersonia aurantiaca: An evaluation of postharvest pulsing solutions to maximise cut flower quality. N. Z. J. Crop Hortic. Sci. 2002, 30, 273-279. [CrossRef]

60. Pérez-Arias, G.A.; Alia-Tejacal, I.; Colinas-León, M.T.; Valdez-Aguilar, L.A.; Pelayo-Zaldívar, C. Postharvest physiology and technology of the tuberose (Polianthes tuberosa L.): An ornamental flower native to Mexico. Hortic. Environ. Biotechnol. 2019, 60, 281-293. [CrossRef]

61. Finger, F.L. Pulsing with sucrose and silver thiosulfate extended the vase life of Consolida ajacis. Acta Hortic. 2001, 543, 63-67. [CrossRef]

62. Pouri, H.A.; Nejad, A.R.; Shahbazi, F. Effects of simulated in-transit vibration on the vase life and post-harvest characteristics of cut rose flowers. Hortic. Environ. Biotechnol. 2017, 58, 38-47. [CrossRef]

63. Skutnik, E.; Rabiza-Świder, J.; Jędrzejuk, A.; Łukaszewska, A. The effect of the long-term cold storage and preservatives on senescence of cut herbaceous peony flowers. Agronomy 2020, 10, 1631. [CrossRef]

64. Doğan, A.; Yılmaz, G.; Erkan, M.; Baktır, I. Effects of sucrose and silver nitrate on the vase life of cut Ranunculus asiaticus L. Acta Hortic. 2013, 1002, 341-348. [CrossRef]

65. Rattanawisalanon, C.; Ketsa, S.; van Doorn, W.G. Effect of aminooxyacetic acid and sugars on the vase life of Dendrobium flowers. Postharvest Biol. Technol. 2003, 29, 93-100. [CrossRef]

66. Fujino, D.W.; Reid, M.S.; Yang, S. Effects of aminooxyacetic acid on postharvest characteristics of carnation. Acta Hortic. 1981, 113, 59-64. [CrossRef]

67. Galati, V.C.; Marques, K.M.; Muniz, A.C.C.; Silva, J.P.; Guimarães, J.E.R.; Mattiuz, C.F.M.; Mattiuz, B.H. Use of calcium chloride in postharvest treatment of Alstroemeria cut flowers. Acta Hortic. 2015, 1104, 267-272. [CrossRef]

68. Çelikel, F.G.; Reid, M.S.; Jiang, C.-Z. Postharvest physiology of cut Gardenia jasminoides flowers. Sci. Hortic. 2020, $261,108983$. [CrossRef]

69. Yun Mi, L.; Sang Kun, P.; Wan Soon, K. Antibacterial effect of chlorine dioxide on extending the vase life of cut gerbera 'Jenny'. Flower Res. J. 2014, 22, 161-166. [CrossRef]

70. Gholami, M.; Rahemi, M.; Rastegar, S. Effect of pulse treatment with sucrose, exogenous benzyl adenine and gibberellic acid on vase life of cut rose 'Red One'. Hortic. Environ. Biotechnol. 2011, 52, 482. [CrossRef]

71. Pinto, A.C.R.; Mello, S.C.; Geerdink, G.M.; Minami, K.; Oliveira, R.F.; Barbosa, J.C. Benzyladenine and gibberellic acid pulse on postharvest of Calathea louisae cut foliage. Acta Hortic. 2007, 755, 397-402. [CrossRef]

72. Van Meeteren, U. Water relations and keeping-quality of cut Gerbera flowers. I. The cause of stem break. Sci. Hortic. 1978, 8, 65-74. [CrossRef]

73. Ahmad, I.; Saleem, M.; Dole, J. Postharvest performance of cut 'White Prosperity' gladiolus spikes in response to nano- and other silver sources. Can. J. Plant Sci. 2016, 96, 511-516. [CrossRef]

74. Kofranek, A.M.; Paul, J.L. the value of impregnating cut stems with high concentrations of silver nitrate. Acta Hortic. 1975, 41, 199-206. [CrossRef]

75. Sharma, R.; Bhardwaj, S. Effect of silver thiosulphate, silver nitrate and distilled water on flower quality and vase life of cut carnation flowers. Bioscan 2015, 10, 1483-1487.

76. Elgimabi, M.E.N.E. Vase life extension of rose cut flowers (Rosa hybirida) as influenced by silver nitrate and sucrose pulsing. Am. J. Agric. Biol. Sci. 2011, 6, 128-133. [CrossRef]

77. Teixeira da Silva, J. The cut flower: Postharvest considerations. J. Biol. Sci. 2003, 3, 406-442. [CrossRef]

78. Skutnik, E.; Jędrzejuk, A.; Rabiza-Świder, J.; Rochala-Wojciechowska, J.; Latkowska, M.; Łukaszewska, A. Nanosilver as a novel biocide for control of senescence in garden cosmos. Sci. Rep. 2020, 10, 10274. [CrossRef] [PubMed]

79. Ichimura, K.; Taguchi, M.; Norikoshi, R. Extension of the vase life in cut roses by treatment with glucose, isothiazolinonic germicide, citric acid and aluminum sulphate solution. Agric. Res. Q. 2006, 40, 263-269. [CrossRef]

80. Doi, M.; Reid, M. Sucrose improves the postharvest life of cut flowers of a hybrid limonium. HortScience 1994, 30. [CrossRef]

81. Ichimura, K. Improvement of postharvest life in several cut flowers by the addition of sucrose. Agric. Res. Q. 1998, 32, 275-280.

82. Kiamohammadi, M.; Golchin, A.; Hashemabadi, D. The effects of different floral preservative solutions on keeping quality of cut lisianthus (Eustoma grandiflorum). Acta Hortic. 2010, 877, 1749-1755. [CrossRef]

83. Reid, M.S.; Jiang, C.-Z. Postharvest biology and technology of cut flowers and potted plants. Hortic. Rev. 2012, 40, 1-54. [CrossRef]

84. Chuang, Y.-C.; Chang, Y.-C.A. The role of soluble sugars in vase solutions during the vase life of Eustoma grandiflorum. HortScience 2013, 48, 222. [CrossRef]

85. Doorn, W.G. Role of soluble carbohydrates in flower senescence: A survey. Acta Hortic. 2001, 543, 179-183. [CrossRef]

86. Yahia, E.M.; Carrillo-López, A.; Bello-Perez, L.A. Chapter 9-Carbohydrates. In Postharvest Physiology and Biochemistry of Fruits and Vegetables; Yahia, E.M., Ed.; Woodhead Publishing: Oxford, UK, 2019; pp. 175-205. [CrossRef]

87. Pun, U.; Ichimura, K. Role of sugars in senescence and biosynthesis of ethylene in cut flowers. Jpn. Agric. Res. Q. 2003, 37, 219-224. [CrossRef] 
88. Lopez, F.B.; Barclay, G.F. Chapter 4-Plant Anatomy and Physiology. In Pharmacognosy; Badal, S., Delgoda, R., Eds.; Academic Press: Boston, MA, USA, 2017; pp. 45-60. [CrossRef]

89. Kottapalli, J.; David-Schwartz, R.; Khamaisi, B.; Brandsma, D.; Lugassi, N.; Egbaria, A.; Kelly, G.; Granot, D. Sucrose-induced stomatal closure is conserved across evolution. PLoS ONE 2018, 13, e0205359. [CrossRef] [PubMed]

90. Dekkers, B.J.W.; Schuurmans, J.A.M.J.; Smeekens, S.C.M. Interaction between sugar and abscisic acid signalling during early seedling development in Arabidopsis. Plant Mol. Biol. 2008, 67, 151-167. [CrossRef] [PubMed]

91. Asad, M.A.U.; Zakari, S.A.; Zhao, Q.; Zhou, L.; Ye, Y.; Cheng, F. Abiotic stresses intervene with ABA signaling to induce destructive metabolic pathways leading to death: Premature leaf senescence in plants. Int. J. Mol. Sci. 2019, 20, 256. [CrossRef]

92. Knee, M. Selection of biocides for use in floral preservatives. Postharvest Biol. Technol. 2000, 18, 227-234. [CrossRef]

93. Cowan, M.M. Plant products as antimicrobial agents. Clin. Microbiol Rev. 1999, 12, 564-582. [CrossRef]

94. Ghorbanpour, M.; Bhargava, P.; Varma, A.; Choudhary, D.K. Biogenic Nano-Particles and Their Use in Agro-Ecosystems; Springer Nature: Gateway East, Singapore, 2020. [CrossRef]

95. Mughal, B.; Zaidi, S.Z.; Zhang, X.; Hassan, S.U. Biogenic nanoparticles: Synthesis, characterisation and applications. Appl. Sci. 2021, 11, 2598. [CrossRef]

96. Meena, M.; Zehra, A.; Swapnil, P.; Marwal, A.H.; Yadav, G.; Sonigra, P. Endophytic nanotechnology: An approach to study scope and potential applications. Front. Chem. 2021, 9, 47. [CrossRef]

97. Yadeta, K.A.; J Thomma, B.P.H. The xylem as battleground for plant hosts and vascular wilt pathogens. Front. Plant Sci. 2013, 4, 97. [CrossRef]

98. Ha, S.T.T.; Lim, J.H.; In, B.C. Extension of the vase life of cut roses by both improving water relations and repressing ethylene responses. Hortic. Sci. Technol. 2019, 37, 65-77. [CrossRef]

99. Darras, A.I. Postharvest Disease Management. In Handbook of Florists' Crops Diseases; McGovern, R.J., Elmer, W.H., Eds.; Springer International Publishing: Cham, Switzerland, 2016; pp. 1-27. [CrossRef]

100. Van Doorn, W.G. Vascular occlusion in stems of cut rose flowers: A survey. Acta Hortic. 1995, 405, 58-66. [CrossRef]

101. Van Doorn, W.G. Vascular Occlusion in Stems of Cut Rose Flowers. Doctor's Thesis, Agricultural University, Wageningen, The Netherlands, 1993.

102. Van Doorn, W.G.; Otma, E. Vascular occlusion in cut flowering rose stems exposed to air: Role of water entry into the lumina of the xylem conduits opened by cutting. J. Plant Physiol. 1995, 145, 78-82. [CrossRef]

103. Kishimoto, K. Effect of post-harvest management on scent emission of carnation cut flowers. Hort. J. 2021, 90, 341-348. [CrossRef]

104. Rabiza-Świder, J.; Skutnik, E.; Jędrzejuk, A.; Łukaszewska, A. Postharvest treatments improve quality of cut peony flowers. Agronomy 2020, 10, 1583. [CrossRef]

105. Kazemi, M.; Abdossi, V.; Kalateh Jari, S.; Ladan Moghadam, A.R. Effect of pre- and postharvest salicylic acid treatment on physio-chemical attributes in relation to the vase life of cut rose flowers. J. Hortic. Sci. Biotechnol. 2018, 93, 81-90. [CrossRef]

106. Combrink, N.J.J. Calcium improves gerbera (Gerbera hybrida) vase life. J. Plant Soil 2018, 35, 235-236. [CrossRef]

107. Singh, K.; Singh, P.J.; Kumar, R. Effect of some chemicals on keeping quality of cut roses. Adv. Hortic. Sci. $2004,18,161-167$.

108. Put, H.M.C.; Clerkx, A.C.M.; Boekestein, A. Aluminium sulphate restricts migration of Bacillus subtilis in xylem of cut roses: A scanning electron microscope study. Sci. Hortic. 1992, 51, 261-274. [CrossRef]

109. Farokhzad, A.R.; Khalighi, A.; Mostofi, Y.; Naderi, R. Effect of some chemical treatments on quality and vase life of lisianthus (Eustoma grandiflora) cut flowers. Acta Hortic. 2008, 768, 479-486. [CrossRef]

110. Damunupola, J.W.; Joyce, D.C. When is a vase solution biocide not, or not only, antimicrobial? Soc. Hortic. Sci. 2008, 77, 211-228. [CrossRef]

111. Seyf, M.; Khalighi, A.; Mostofi, Y.; Naderi, R. Effect of sodium nitroprusside on vase life and postharvest quality of a cut rose cultivar (Rosa hybrida ‘Utopia'). J. Agric. Sci. 2012, 4, 174-181. [CrossRef]

112. Lee, Y.B.; Kim, W.S. Improving vase life and keeping quality of cut rose flowers using a chlorine dioxide and sucrose holding solution. Hortic. Sci. Technol. 2018, 36, 380-387. [CrossRef]

113. Dung, C.D.; Seaton, K.; Singh, Z. Influence of type and concentration of sugars, supplemented with 8-hydroxyquinoline sulphate, on the vase life of waxflower. Folia Hortic. 2017, 29, 39-49. [CrossRef]

114. Liu, J.; Zhang, Z.; Joyce, D.C.; He, S.; Cao, J.; Lv, P. Effects of postharvest nano-silver treatments on cut-flowers. Acta Hortic. 2009, 847, 245-250. [CrossRef]

115. Li, X.; Xu, H.; Chen, Z.-S.; Chen, G. Biosynthesis of nanoparticles by microorganisms and their applications. J. Nanomater. 2011, 2011, 270974. [CrossRef]

116. Nazemi Rafi, Z.; Ramezanian, A. Vase life of cut rose cultivars 'Avalanche' and 'Fiesta' as affected by nano-silver and S-carvone treatments. J. Bot. 2013, 86, 68-72. [CrossRef]

117. Lü, P.; Cao, J.; He, S.; Liu, J.; Li, H.; Cheng, G.; Ding, Y.; Joyce, D.C. Nano-silver pulse treatments improve water relations of cut rose cv. Movie Star flowers. Postharvest Biol. Technol. 2010, 57, 196-202. [CrossRef]

118. Che Husin, N.M.; Liu, J.; Joyce, D.C.; Irving, D.E. Cutting wound ethylene production does not limit the vase life of Acacia holosericea. Sci. Hortic. 2016, 212, 35-48. [CrossRef]

119. Ha, S.T.T.; In, B.C.; Choi, H.W.; Jung, Y.O.; Lim, J.H. Assessment of pretreatment solutions for improving the vase life and postharvest quality of cut roses (Rosa hybrida L. 'Jinny'). Flower Res. J. 2017, 25, 101-109. [CrossRef] 
120. Ichimura, K.; Fujiwara, T.; Yamauchi, Y.; Horie, H.; Kohata, K. Effects of tea-seed saponins on the vase life, hydraulic conductance and transpiration of cut rose flowers. Agric. Res. Q. 2005, 39, 115-119. [CrossRef]

121. Wu, L.Y.; Xiao, H.; Zhao, W.J.; Sun, P.; Lin, J.K. Effect of green tea extract powder on the vase-life of fresh-cut rose (Rosa hybrida L.) 'Carola' stems. J. Hortic. Sci. Biotechnol. 2016, 91, 279-284. [CrossRef]

122. Akhtar, G.; Rajwana, I.A.; Sajjad, Y.; Shehzad, M.A.; Amin, M.; Razzaq, K.; Ullah, S.; Faried, H.N.; Farooq, A.; Sami, U.; et al. Do natural leaf extracts involve regulation at physiological and biochemical levels to extend vase life of gladiolus cut flowers? Sci. Hortic. 2021, 282, 110042. [CrossRef]

123. Shokalu, A.O.; Akintoye, H.A.; Olatunji, M.T.; Adebayo, A.G.; James, I.E. Use of organic and inorganic solutions for extending the vase life of cut Heliconia 'Golden Torch' flowers. Acta Hortic. 2019, 1263, 497-502. [CrossRef]

124. Maity, T.R.; Samanta, A.; Jana, D.; Saha, B.; Datta, S. Effect of Piper betle leaf extract on post-harvest physiology and vascular blockage in relation to vase life and keeping quality of cut spike of tuberose (Polianthes tuberosa L. cv. Single). Ind. J. Plant Physiol. 2014, 19, 250-256. [CrossRef]

125. Solgi, M. The application of new environmentally friendly compounds on postharvest characteristics of cut carnation (Dianthus caryophyllus L.). Rev. Bras. Bot. 2018, 41, 515-522. [CrossRef]

126. Hassan, F.A.S.; Fetouh, M.I. Does moringa leaf extract have preservative effect improving the longevity and postharvest quality of gladiolus cut spikes? Sci. Hortic. 2019, 250, 287-293. [CrossRef] 